Int. J. Environ. Res. Public Health 2004, 1(2), 90-99

International Journal of

\title{
Pentachlorophenol-Induced Cytotoxic, Mitogenic, and Endocrine- Disrupting Activities in Channel Catfish, Ictalurus punctatus
}

\author{
Waneene C. Dorsey ${ }^{1,2}$ and Paul B. Tchounwou ${ }^{1 *}$ \\ ${ }^{1}$ Molecular Toxicology Research Laboratory, NIH - Center for Environmental Health, School of Science and Technology, \\ Jackson State University, 1400 Lynch Street, P.O. Box 18540, Jackson, Mississippi, USA. \\ ${ }^{2}$ Wildlife Biology Unit, Grambling State University, Grambling, LA 71245, USA. \\ ${ }^{*}$ Correspondence to Dr. Paul B. Tchounwou. Email: paul.b.tchounwou@jsums.edu
}

Received: 10 April 2004 / Accepted: 02 June 2004 / Published: 30 September 2004

\begin{abstract}
Pentachlorophenol (PCP) is an organochlorine compound that has been widely used as a biocide in several industrial, agricultural, and domestic applications. Although it has been shown to induce systemic toxicity and carcinogenesis in several experimental studies, the literature is scarce regarding its toxic mechanisms of action at the cellular and molecular levels. Recent investigations in our laboratory have shown that PCP induces cytotoxicity and transcriptionally activates stress genes in human liver carcinoma $\left(\mathrm{HepG}_{2}\right)$ cells [1]. In this research, we hypothesize that environmental exposure to PCP may trigger cytotoxic, mitogenic, and endocrine-disrupting activities in aquatic organisms including fish. To test this hypothesis, we carried out in vitro cultures of male channel catfish hepatocytes, and performed the fluorescein diacetate assay (FDA) to assess for cell viability, and the Western Blot analysis to assess for vitellogenin expression following exposure to PCP. Data obtained from FDA experiments indicated a strong dose-response relationship with respect to PCP cytotoxicity. Upon 48 hrs of exposure, the chemical dose required to cause $50 \%$ reduction in cell viability $\left(\mathrm{LD}_{50}\right)$ was computed to be $1,987.0 \pm 9.6 \mu \mathrm{g}$ $\mathrm{PCP} / \mathrm{mL}$. The NOAEL and LOAEL were $62.5 \pm 10.3 \mu \mathrm{g} \mathrm{PCP} / \mathrm{mL}$ and $125.0 \pm 15.2 \mu \mathrm{g} \mathrm{PCP} / \mathrm{mL}$, respectively. At lower levels of exposure, PCP was found to be mitogenic, showing a strong dose- and time-dependent response with regard to cell proliferation. Western Blot analysis demonstrated the potential of PCP to cause endocrine-disrupting activity, as evidenced by the up regulation of the $125-\mathrm{kDa}$ vitellogenin protein the hepatocytes of male channel catfish.
\end{abstract}

Key words: pentachlorophenol, catfish hepatocytes, cytotoxicity, vitellogenin, estrogenic activity

\section{Introduction}

Global production and use of organochlorine pesticides have resulted in ubiquitous residues in soil, water, and air samples. Exposure to this family of pesticides has been strongly connected to endocrine disruption activity, resulting in adverse human and wildlife developmental defects, disease, and potentially cancer [2, 3]. Major groups of organochlorine pesticides include chlorinated benzenes, cyclodienes, cyclohexanes, and dichlorodiphenylethanes. Collectively, they have become key sources of environmental contamination because of landfill leachate, effluents from pesticide manufacturing plants, and exhaust gases from the combustion of woods [4]. Although some organochlorine pesticides such as hexachlorobenzene $(\mathrm{HCH})$ and pentachlorophenol (PCP) are used as fungicides, most of them are primarily known for their effective biocidal action against a wide variety of insects and microorganisms. 
During the early 1940s, organochlorine pesticides were commercially manufactured in the United States and heavily used in agriculture for the control of insects. Widespread distribution of these pesticides peaked in the early 1960s because of extensive use in agricultural, industrial, and domestic applications. It has been found that parent organochlorine pesticides often contain impurities that are precursors of toxic metabolites. These by-products are considered to be more dangerous as well as persistent in the environment $[5,6]$. For example, PCP metabolizes to tetrachlorophenol, $\mathrm{HCH}$, and various dioxins and furans. The isometric form, beta-HCH is more persistent than PCP. Subsequently, polychlorinated dibenzo- $p$-dioxin (PCDD) and polychlorinated dibenzofuran (PCDF) compounds are found in areas where PCP has been used or where PCP wastes have been disposed [2, 7]. The slow biodegradation rate and lipophilic nature of organochlorine pesticides have contributed to pervasive contamination and persistence in the environment. For these reasons, the United States Environmental Protection Agency (U.S. EPA) banned many organochlorine pesticides in the 1970's and 1980s.

There is now accumulating evidence indicating that organochlorine pesticides can compromise the integrity of the male reproductive system of fish, reptiles and mammals [8-10]. Additionally, studies have shown that exposure to low levels of organochlorine residues can result in physiological disturbances and reproductive disruption in humans and other animals [3, 11-17]. Organochlorine chemicals, including DDT, polychlorinated biphenyls (PCBs), dioxins, lindane, hexachlorobenzene, and PCP are generally cited as potential endocrine-disrupting substances [2, 18, 19]. Endocrine-disrupting mechanisms of these chemicals are ardently linked to mimicking hormonal estrogens $[3,18$, 20]. Furthermore, chlorinated compounds, that mimic hormones, have the ability to induce proliferate responses [3]. Exposure to organochlorine pesticides in the aquatic environment has resulted in towering occurrences of vitellogenin $(\mathrm{Vtg})$ synthesis in species of male fish [21-23]. Furthermore, the induction of Vtg in male fish exposed to environmental contaminants has become an attractive indicator of potential estrogenic potency [21, 24-26].

PCP is a chlorophenol herbicide and prevalent wood preservative in the United States. It has been used worldwide in fungicide, insecticide, and herbicide applications. The biocidal action of PCP protects timber from fungal rot and wood-boring insects, thus extending the life of wood products. PCP is one of the most heavily used organochlorine pesticides in the United States, preceded by the herbicides atrazine, and alachlor [27]. It was first manufactured in 1841, and commercially produced in 1936 [28, 29]. By 1967, sodium pentachlorophenate (Na-PCP) was used expansively in agricultural and industrial applications because pure-grade PCP was virtually insoluble in water $[30,31]$. Other applications of PCP include leather tanning, cooling-tower algae and fungi control, slime and fungus control in photographic solutions, and in other industrial activities for protection of plants and products from biological degradation [13, 32, 33]. PCP was banned as an herbicide, and over-the-counter sales were prohibited in 1987 [34]. In 1988, the U.S. EPA announced the restricted use of PCP in the pulp and paper industry where it is used in paper coatings, sizing, and adhesives and in inks.

A decline in the use of PCP has resulted over years because of U.S. EPA regulations. Nonetheless, from 1987 to 1993 , PCP releases to land and water totaled nearly $100,000 \mathrm{lbs}$ of which about $80 \%$ was to land [34]. Various trade names for PCP include: Penchlorol, Dowicide, EP 30, Permagard, Permasan, Permatox DP-2, Fungifen, Dura Treet II, Glazd Penta, Woodtreat, PentaReady, PentaWR, Chem-tol, Cryptogil oil, Weedone, and Term-I-Trol $[32,34]$. PCP is an ominous pollutant whose environmental pathways lead to the contamination of soil, water, and food. Contamination occurs when the solution migrates from the interior of the wood to the exterior surface, thus leaching into the surrounding soil and groundwater. In addition, spills at industrial facilities and hazardous waste sites are key tributaries to soil contamination. Because of these pathways, drinking water, surface water, groundwater, rain, snow, air and aquatic biota have become common sources for PCP-contamination in the United States [35]. In aquatic ecosystems, levels of PCP are increased up to 10,000 times higher than the concentration in the surrounding waters [36]. PCP is acutely and chronically highly toxic to cold and warm water fish, and moderately toxic to other freshwater and marine organisms [37]. Bioaccumulation is a significant factor that affects several species of fish and invertebrates.

PCP is a systemic toxicant to the nervous, immune, and reproductive systems and causes injury to hepatic and urinary organs $[36,37]$. PCP has been established as a carcinogen in animal laboratory studies, and a probable human carcinogen-Group $B_{2}[38,39]$. High doses of oral exposures and near lethal levels of PCP can disturb the developmental phase in animals. Series of experiments report that exposures to high levels of PCP are embryolethal in rats $[40,41]$. Also low doses of oral administration during the critical period of pregnancy in hamsters result in fetal deaths [40]. In addition, another study demonstrated that PCP-treated rams, from conception to necropsy at 28 weeks of age, increased in scrotal circumference, induced acute semi-niferous tubule atrophy, and reduced epididymal sperm density [11]. Another study characterized patterns of abnormal reproductive morphology when PCP exposure in female ewes caused an increase in severity of oviductal intraepithelial cysts [17]. Aggravation of the developmental phase in mink was reported when PCP caused a decrease in reproductive competence, whelping rate, and fertility [42]. More recently, another study reported that topical exposures to PCP in the Japanese medaka embryo increased embryos mortality and that the 
neurula stage was the most sensitive embryonic stage that was intolerant by a single topical exposure of PCP [43]

Prolonged exposure conditions to PCP can result in adverse reproductive effects in humans that are associated with changes in the endocrine gland function, and immunological dysfunction [36]. Chronic exposure to PCP is often a widespread cause of reproductive toxicity in women. Epidemiological studies have confirmed that women with a history of spontaneous abortion, unexplained infertility, menstrual disorders, and mild ovarian deficiency have elevated levels of PCP in their blood [44].

Recent investigations in our laboratory have shown that PCP triggers the induction of various genes in human liver carcinoma $\left(\mathrm{HepG}_{2}\right)$ cells, and is involved in Phase I biotransformation, protein structure alteration, the inflammatory response, and DNA damage $[1,45]$. There are few reports in which PCP has been linked to endocrine-disrupting activity. In the present investigation, we hypothesize PCP-treatment of catfish hepatocyes may trigger cytotoxic, mitogenic, and endocrine-disrupting responses.

\section{Materials and Methods}

\section{Chemicals and Reagents}

Pentachlorophenol $\left(\mathrm{C}_{6} \mathrm{Cl}_{5} \mathrm{OH}, \mathrm{CAS}\right.$ No. 87-86-5, Lot No. 01530TS), with purity $98.0 \%$ was purchased from Aldrich Chem Co., (Milwaukee, WI). Dulbecco's Modified Eagle's Minimal Essential Medium (DMEM, Lot No. 109721) and tissue culture supplements were purchased from Life Technologies (Grand Island, New York). Twelve percent SDS-PAGE gels were obtained from ISC BioExpress (Kaysville, UT). c-fos primary monoclonal antibody, was purchased from Oncogene Research Products (San Diego, CA), while vitellogenin monoclonal anti-carp primary antibody was purchased from Biosense Laboratories (Bergen, Norway). Alkaline phosphatase conjugated donkey anti-goat IgG and goatanti-mouse IgG secondary antibodies, and BCIP/NBT color development substrate were purchased from Promega (Madison, WI). Protein assay reagent was obtained from Xenometrix, Inc. (Boulder, CO). Accumax was purchased from Innovative Cell Technologies (San Diego, CA).

\section{Preparation and Culture of Catfish Hepatocytes}

Sexually mature male channel catfish, measuring 20 to $30 \mathrm{~cm}$ in length, were obtained from Grambling State University Aquaculture Facility, Grambling, LA. On day one, the catfish were transported to the laboratory. Subsequently, catfish were placed on ice for 10 minutes to numb incision area. An incision was made on the ventral side of the catfish where the liver was surgically removed. Hepatocyes were isolated by breaking up the liver into small chunks, several square millimeters.
Accumax solution of $1.0 \mathrm{~mL}$ per milligram of tissue $(\mathrm{w} / \mathrm{v})$ was employed to dissociate hepatocytes from primary tissue. Tissue samples were incubated in Accumax on a platform rocker at $37^{\circ} \mathrm{C}$ up to 25 minutes. Following removal of cell debris, the hepatocytes were seeded into two $75 \mathrm{~cm}^{2}$ flasks containing $25 \mathrm{~mL}$ of fresh Dulbecco's Minimum Essential Medium (DMEM) + $10 \%$ fetal bovine serum (FBS) $+1 \%$ Penicillin/Streptomycin, and incubated at $37^{\circ} \mathrm{C}$ in a $5 \%$ $\mathrm{CO}_{2}$ incubator. On day two, the medium was replaced with fresh ${ }^{+}$DMEM and hepatocytes were examined each day for cell density and morphology prior to treatment.

\section{Cytotoxicity and Cell Proliferation Experiments}

The fluorescein diacetate (FDA) method was used to assess cell viability once primary cell cultures were established. FDA, an uncharged fluorescent dye, is rapidly esterified once it enters the cell. The viability of the cells is assessed from the hydrolysis product, fluorescein, which cannot escape from live cells. Fish hepatocytes grown to $80-95 \%$ confluency were washed with phosphate buffer saline (PBS), trypsinized with 5 $\mathrm{mL}$ of $0.25 \%(\mathrm{w} / \mathrm{v})$ trypsin- $0.03 \%(\mathrm{w} / \mathrm{v})$ EDTA, diluted, and counted $\left(2.5-5 \times 10^{5}\right.$ cells/well). Next, cell suspensions of $160 \mu \mathrm{l}$ DMEM (minus supplements) were seeded into a 96-well microtiter culture plate for $24 \mathrm{~h}$ at $37^{\circ} \mathrm{C}$ in a $5 \% \mathrm{CO}_{2}$ incubator. The next day, $40 \mu \mathrm{l}$ aliquots of PCP solutions at varying concentrations were added to each well. Cells were placed in the incubator for $48 \mathrm{~h}$ at $37^{\circ} \mathrm{C}$ in $5 \% \mathrm{CO}_{2}$. Following $48 \mathrm{~h}$ period, medium mixture was removed and culture plate was washed once with $200 \mu \mathrm{l}$ PBS/well. Aliquots of $100 \mu \mathrm{l}$ FDA solution $(10 \mu \mathrm{g} / \mathrm{mL}$ in PBS), were added columnwise to each well and incubated at $37^{\circ} \mathrm{C}$ for $30-60$ minutes before reading the fluorescence. A Fluoroskan Ascent FL spectrofluorometer by Labsystems (Beverly, MA) at excitation and emission wavelengths of 485 and $538 \mathrm{~nm}$, was used to measure absorbance.

\section{Sample Collection and Protein Determination}

Primary catfish hepatocytes were grown to confluency in polystyrene multidish 6-well plates. About $1 \times 10^{6}$ cells per well were treated with duplicate $0,750,1500$, and $2000 \mu \mathrm{g} / \mathrm{mL}$ concentrations of PCP for $48 \mathrm{hr}$. Untreated cells served as controls. After treatment with PCP, an equal volume $(200 \mu \mathrm{L})$ of sample buffer $(0.2 \mathrm{~mol} / \mathrm{L}$ Tris, $\mathrm{pH} 6.8,1 \% \mathrm{SDS}, 30 \%$ glycerol, $7.5 \% \beta$-mercaptoethanol, $0.1 \%$ bromophenol blue) was added to each well. Cells were mechanically dislodged, transferred to microcentrifuge tubes, and heated at $95^{\circ} \mathrm{C}$ for $10 \mathrm{~min}$. Samples were then frozen until future use. The Bradford protein assay in a microtiter plate (Falcon 96-well microtiter plates) format was used for the determination of protein concentrations in samples. Bovine serum albumin (BSA) $(1 \mathrm{mg} / \mathrm{mL})$ was dissolved in saline and used as the protein standard. Protein reagent $(180 \mu \mathrm{l})$ was added to 21 wells of the microtiter 
plate. Triplicate volumes of $0,2,4,6,10,15$, and $20 \mu \mathrm{l}$ of BSA $(1 \mathrm{mg} / \mathrm{mL})$ were transferred into assigned wells. Distilled water was added to bring total volume to $200 \mu \mathrm{l}$ per well. Without prior incubation, the total proteins for catfish cell lysates were quantitatively measured at 600 $\mathrm{nm}$ absorbance using the Multiskan Ascent microplate reader (Labsystems, Beverly, MA).

\section{Western Blot Analysis for identification of Specific Cellular Proteins}

Catfish hepatocytes were grown to confluency in polystyrene multidish 6-well plates. About $2 \times 10^{6}$ cells per well were treated with duplicate $0,750,1500$, and $2000 \mu \mathrm{g} / \mathrm{mL}$ concentrations of PCP for $48 \mathrm{hr}$. Untreated cells served as controls. Whole cell extracts from catfish hepatocytes $(20 \mu \mathrm{g} / \mathrm{mL})$ containing an equal volume of sample buffer was heated at $100^{\circ} \mathrm{C}$ for $10 \mathrm{~min}$ and electrophoresed on a $12 \%$ SDS-polyacramide gel. Separated proteins were transferred onto a nitrocellulose membrane on ice in $20 \mathrm{mM}$ Tris base, $150 \mathrm{mM}$ glycine, $20 \%$ methanol, $\mathrm{pH}$ 8.0. Subsequently, membranes were blocked $(10 \mathrm{~mL}$ of Tris-buffered saline 0.1 Tween-20 [TBST] with $5 \%$ nonfat dry milk) for $1 \mathrm{~h}$ at room temperature. Detection of the $c$-fos gene protein induced by PCP was probed with a $c$-fos $(15: 1000)$ primary monoclonal antibody that was further detected with a 1:750 dilution of alkaline-conjugated goat anti-mouse $\mathrm{IgG}$, secondary antibody. A dilution of 1:5000 Vtg carp anti-mouse primary monoclonal antibody was used to elicit the Vtg protein expression. Vtg was further detected with a 1:100 dilution of alkaline phosphataseconjugated donkey anti-goat IgG, secondary antibody. BCIP/NBT color substrate was incorporated to develop protein bands. Immunoblot 1-D protein bands were assessed for relative abundance by TotalLab computer software (Nonlinear USA Inc. Durham, NC).

\section{Results}

\section{Cytotoxicity of PCP}

The effects of PCP on the viability of catfish hepatocytes are shown in Figure 1. PCP-cytotoxicity was determined in vitro using primary cultured hepatocytes from male channel catfish. Catfish hepatocytes were exposed for $48 \mathrm{~h}$ to seven incremental concentrations of PCP $(62.5,125,250,500,1000,2000$ and $4000 \mu \mathrm{g} / \mathrm{mL}$ ), excluding control. Exposure to PCP caused a dose-dependent decrease in cell viability; indicating acute toxicity. Cell viability percentage values of PCP-treated hepatocytes were compared to the untreated control $(100 \%$ cell survival) to determine if there were any significant differences. Upon $48 \mathrm{hrs}$ of exposure, the PCP concentration required to reduce cell viability by $50 \%\left(\mathrm{LC}_{50}\right)$, was computed to be $1987.0 \pm$ $9.6 \mu \mathrm{g} \mathrm{PCP} / \mathrm{mL}$. NOAEL and LOAEL toxic endpoints were recorded as $62.5 \pm 10.3$ and $125.0 \pm 15.2 \mu \mathrm{g}$ PCP $/ \mathrm{mL}$, respectively.

\section{Mitogenic Activity of PCP}

The mitogenic effect of PCP on catfish hepatocytes is shown in Figure 2. To determine the mitogenic activity of PCP, we expose catfish hepatocytes to sublethal concentrations of PCP $(0, .484, .968,1.94$, $3.87,7.75,15.5$, and $31 \mu \mathrm{g} / \mathrm{mL})$. Untreated hepatocytes were compared to PCP-treated hepatocytes to determine significant differences in stimulatory patterns. Results from this experiment exhibited a concentration and timedependent stimulatory effect on cell proliferation. A consistent fourfold to eightfold increase in cell proliferation was demonstrated with all 24 and 48 h test concentrations. For example, at $48 \mathrm{hrs}$ of exposure, the percentages cell proliferation of catfish hepatocytes were about $100 \%, 600 \%, 800 \%, 500 \%, 600 \%, 700 \%, 800 \%$, $900 \%$ in $0, .484,1.94,3.87,7.75,15.5$ and $31 \mu \mathrm{g}$ $\mathrm{PCP} / \mathrm{mL}$, respectively. These results suggest that low doses of PCP are mitogenic in catfish hepatocytes.

\section{Western and Densitometric Analyses for c-fos Expression}

Western Blot and densitometric analyses of $c$-fos expression in PCP-treated male catfish hepatocytes is shown in Figure 3. The $62-\mathrm{kDa}$ c-fos gene protein was identified by Western Blot analysis. To determine the ability of PCP to transcriptionally induce $c$-fos expression, catfish hepatocytes were acutely exposed to various PCP-treatments $(0,750,1500,2000 \mu \mathrm{g} / \mathrm{mL})$. PCP-treated hepatocytes were compared to the untreated control, to determine the magnitude of $c$-fos expression. Upon $48 \mathrm{hrs}$ of exposure, a dose-dependent upregulation of the $c$-fos gene protein was observed at $2000 \mu \mathrm{g}$ $\mathrm{PCP} / \mathrm{mL}$; indicating the mitogenic, inflammatory, and proliferative activity of PCP. Although no detectable protein expressions were observed at other concentrations, these data corroborate previous findings from our laboratory, where PCP simulated a dosedependent overexpression of $c$-fos in $\mathrm{HepG}_{2}$ cells $[1,45]$. Densitometric analysis revealed that $2000 \mu \mathrm{g} \mathrm{PCP} / \mathrm{mL}$ caused a substantial increase of $c$-fos abundance.

\section{Western and Densitometric Analyses for Vtg Expression}

Western Blot and densitometric analyses of Vtg expression in PCP-treated male catfish hepatocytes is shown in Figure 4. A qualitative identification of the $125 \mathrm{kDa}-\mathrm{Vtg}$ protein was made by Western Blot analysis. We tested the ability of PCP to stimulate the induction of the Vtg protein by exposing male catfish hepatocytes to various concentrations of PCP $(0,750$, $1500,2000 \mu \mathrm{g} / \mathrm{mL}$ ) for $48 \mathrm{hrs}$. Untreated hepatocytes were compared to PCP-treated hepatocytes to determine the extent of Vtg expression. A strong induction of the Vtg protein was observed at $750 \mathrm{PCP} \mu \mathrm{g} / \mathrm{mL}$. The ability of PCP to stimulate Vtg production in male catfish hepatocytes, strongly suggests that PCP is an 


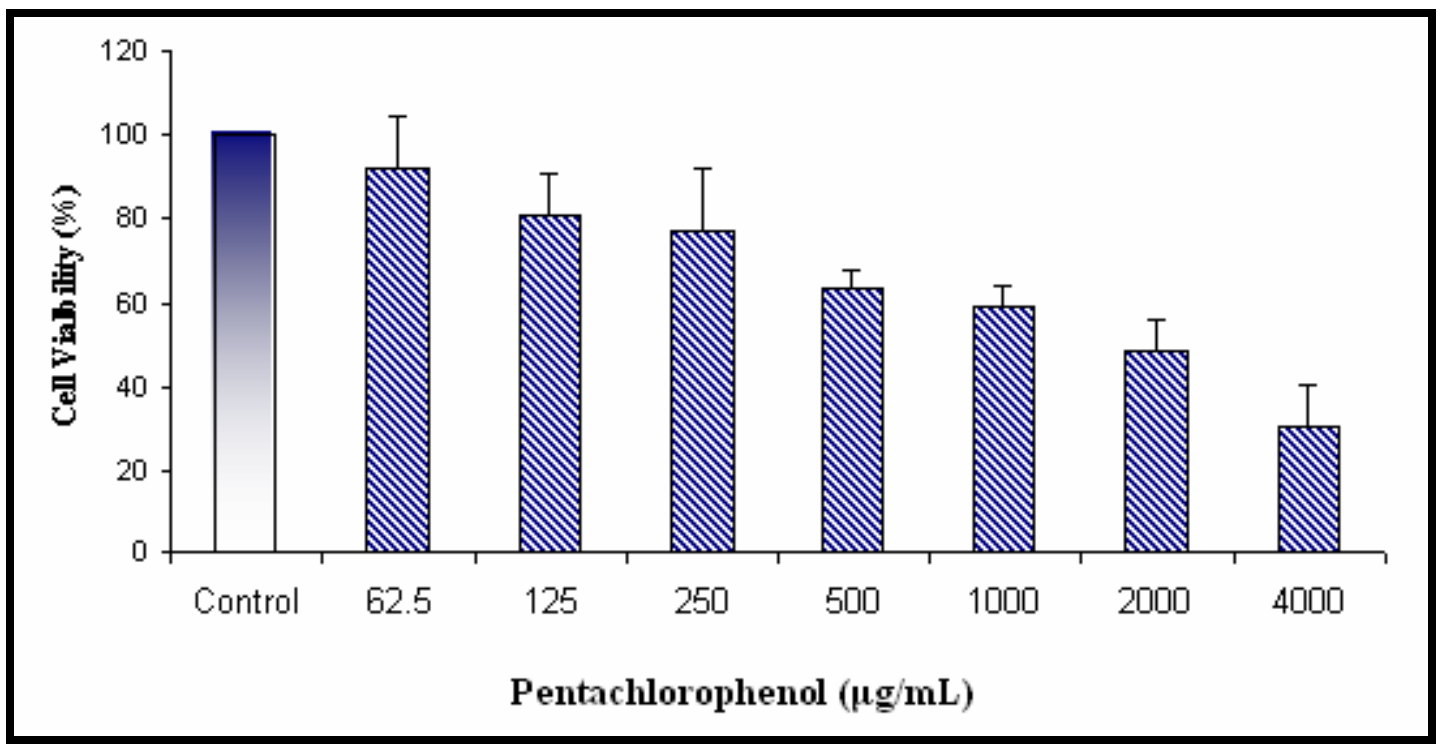

Figure 1: Toxicity of pentachlorophenol to channel catfish hepatocytes. Cell viability of catfish hepatocytes exposed to PCP. The cells were treated with serial dilutions $(0-4000 \mu \mathrm{g} / \mathrm{mL})$ of PCP. Cell viability was measured by FDA assay as indicated in the methodology section. Absorbance readings were converted to percentages cell viability. Bars are means \pm SDs, $n=3$ with 8 replications per concentration. All values are significantly different $(p \leq 0.05)$ from control $(0$ $\mu \mathrm{g} / \mathrm{mL}$ PCP).

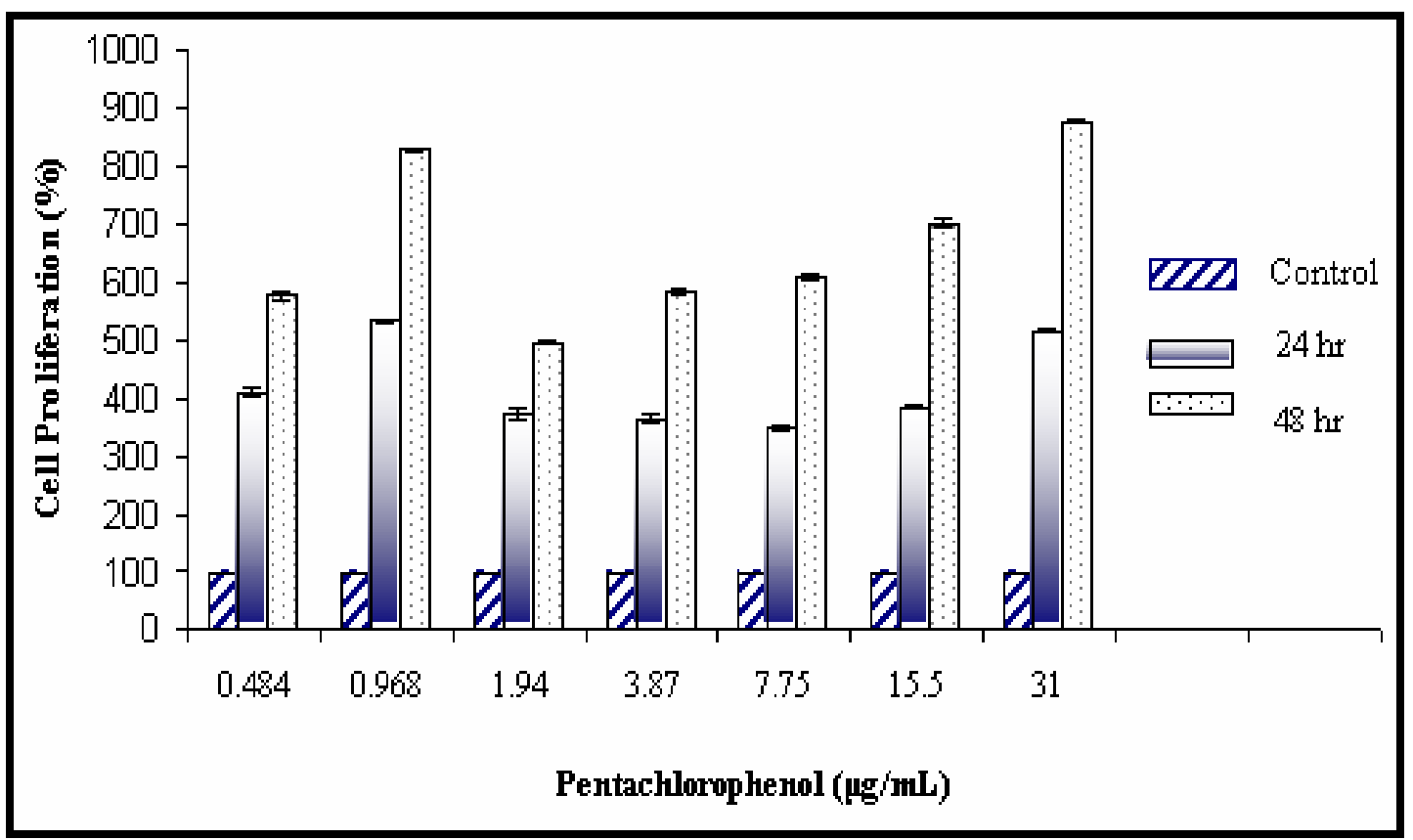

Figure 2: Mitogenic effect of pentachlorophenol on catfish hepatoctes, after $24 \mathrm{hr}$ and $48 \mathrm{hr}$ of exposure. Bars are means $\pm \mathrm{SDs}, \mathrm{n}=3$ with 8 replications per concentration. All values are significantly different from control $(0 \mu \mathrm{g} / \mathrm{mL} \mathrm{PCP}), p \leq 0.001$. 


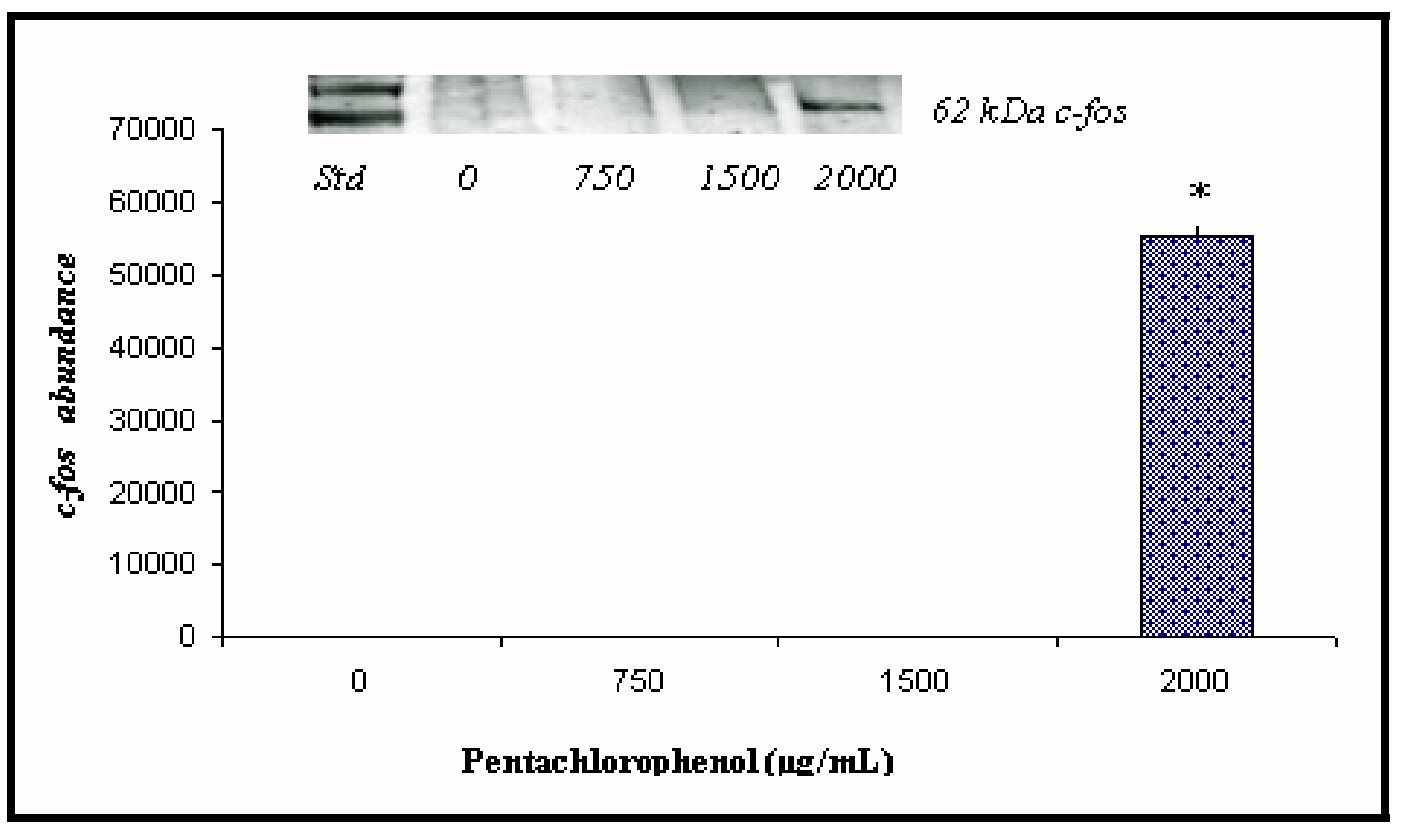

Figure 3: Western Blot for $c$-fos expression and densitometric analysis in PCP-treated channel catfish hepatocytes. Inset shows representative Western analysis. Densitometric analysis shows significant $c$-fos abundance at $2000 \mathrm{ug} / \mathrm{mL}$. Bar represents $c$-fos abundance; values are means \pm SDs, $\mathrm{n}=3$. * Significantly different from control $(0 \mu \mathrm{g} / \mathrm{mL}$ PCP $), p \leq 0.05$.

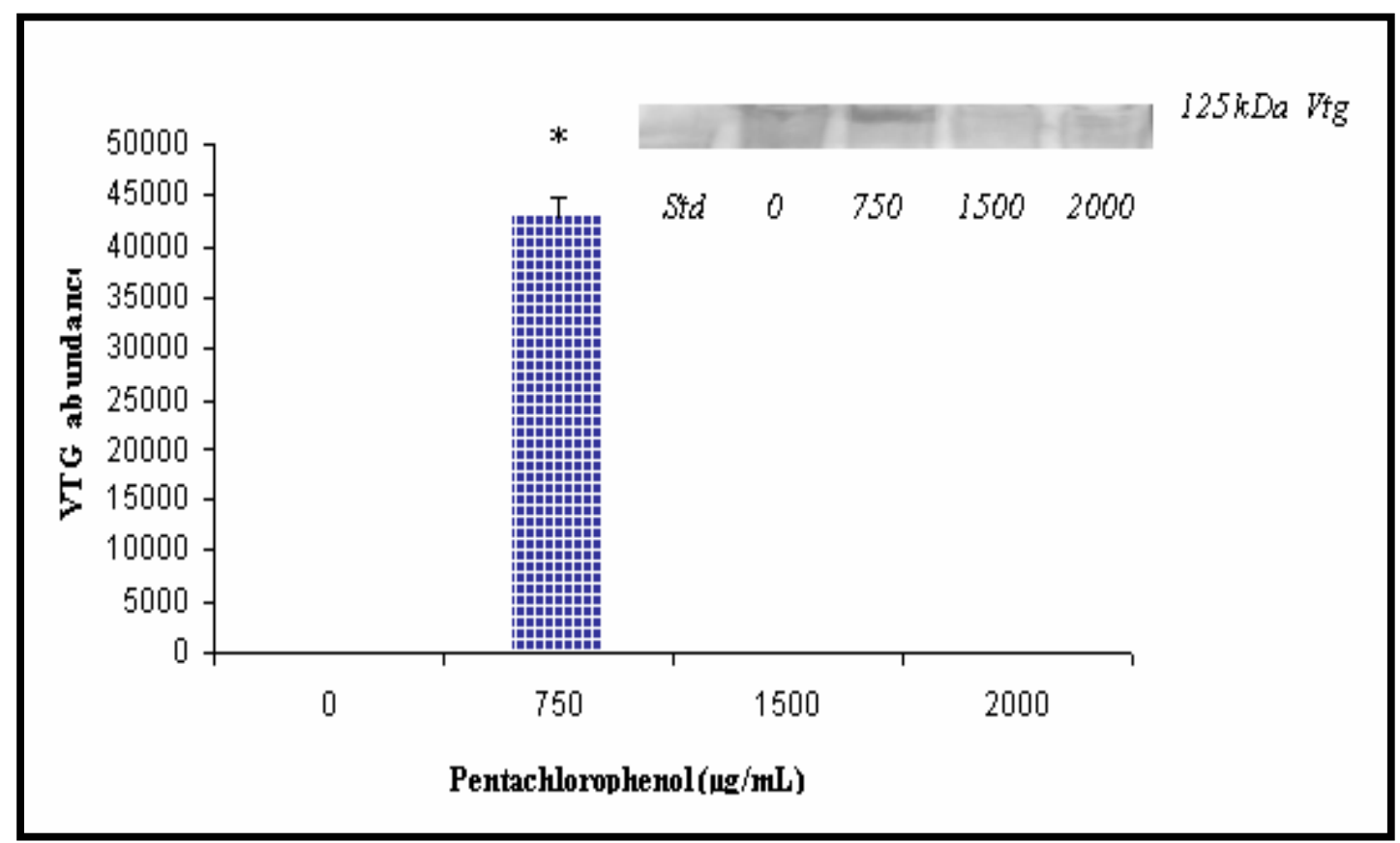

Figure 4: Western Blot for Vtg expression and densitometric analysis in PCP-treated channel catfish hepatocytes. Inset shows representative Western analysis. Densitometric analysis shows a significant increase in Vtg abundance at $750 \mathrm{ug} / \mathrm{mL}$. Bar represents Vtg abundance; values are means \pm SDs, $\mathrm{n}=3$. * Significantly different from control $(0 \mu \mathrm{g} / \mathrm{mL} \mathrm{PCP}), p \leq 0.05$. 
endocrine disrupting compound; and that PCP mimicks the estrogen hormone $[3,18,20]$.

\section{Discussion}

\section{Cytotoxicity Studies}

In the present study, we demonstrated that PCP is acutely toxic to catfish hepatocytes (Figure 1). The FDA assay was employed to assess cell viability. The sensitivity of the assay was based on the ability of the fluorescent dye to enter intact live cells, where is esterified by the esterase enzyme. The product of this hydrolysis, fluorescein, was demonstrated when exposure to PCP significantly reduced the viability of the catfish hepatocytes $\left(\mathrm{LC}_{50}=1,987.0 \pm 9.6 \mu \mathrm{g} \mathrm{PCP} / \mathrm{mL}\right)$. PCP's toxic potency to catfish hepatocytes was dosedependent, indicating that increased levels of PCP caused increased toxicity to catfish hepatocytes. Interestingly, these results are consistent with previous findings from our laboratory that reported a strong doseresponse relationship with respect to the cytotoxic effects of PCP in $\mathrm{HepG}_{2}$ cells $[1,45]$.

Cytotoxicity combined with the slow metabolic breakdown of organochlorine pesticides, can cause deleterious effects in species than consume fish or aquatic invertebrates [10]. Much of the current research shows that PCP is highly persistent in soil, having a halflife of up to 5 years. The persistence of organochlorine pesticides in the environment has been highly linked to pesticide bioaccumulation in aquatic species as well as exceeding guidelines for the protection of aquatic. For example, our PCP-cytotoxicity results are quite consistent with the literature; indicating that surviving fish such as bluegills, large mouth bass, and channel catfish can accumulate up to $19 \mathrm{mg} / \mathrm{kg}, 48 \mathrm{mg} / \mathrm{kg}$, and $221 \mathrm{mg} / \mathrm{kg}$ of PCP in their muscle, gills, and liver, respectively for up to 10 months [46].

\section{Mitogenic Activity of PCP in Catfish Hepatocytes}

Previous studies have pointed out that the mitogenic activity of organochlorine compounds is strongly coupled to signal transduction through the G1 phase of the cell $[3,47]$. In the present study, an in vitro approach was used to investigate whether low levels of PCP have direct mitogenic effects on primary cultured catfish hepatocytes. As a consequence of exposure, accelerated proliferation rates were seen in PCP-treated catfish hepatocytes, consequently from 24 and $48 \mathrm{hr}$ exposure to sublethal doses. The $48 \mathrm{~h}$ exposure resulted in a dosedependent, four-fold to eightfold increase in cell proliferation; indicating that PCP has a substantial mitogenic potential for channel catfish. Moreover, such mitogenic activity was also observed from our previous investigation where sublethal concentrations of PCP were mitogenic to $\mathrm{HepG}_{2}$ cell following $24 \mathrm{hrs}$ of exposure [45]. The mitogenic activity of PCP is further supported by the results of the Western Blot analysis showing a potential activation of the $c$-fos protein catfish hepatocytes.

\section{c-fos Expression in Catfish Hepatocytes}

Among the earliest responses to mitogenic signaling is the activation of transcription factors such as $c$-fos. $c$ fos has been implicated as a positive regulator of cell proliferation $[48,49]$. Recently we demonstrated that PCP has the ability to transcriptionally activate $c$-fos $[1$, 45]. In this study, a dose-response relationship was observed with regard to PCP induction of the $62-\mathrm{kDa} C$ fos protein. We report that an appreciable expression of the $c$-fos protein was seen at the $2000 \mu \mathrm{g} / \mathrm{mL}$ level in PCP-stimulated catfish hepatocytes (Figure 3). The proto-oncogene $c$-fos has been exclusively implicated in cell growth, differentiation, and the inflammatory process. $\quad c$-fos and other immediate early transcription factors are thought to be essential for mitogen-induced progress through the cell cycle. However, the induction of the $c$-fos gene involves both transcriptional and posttranscriptional machinery. Once stimulated, $c$-fos conjoins with c-jun, a transcription factor of the Jun family, and forms the heterodimeric complex, activator protein-1 (AP-1). The up-regulation of the $c$-fos protein is more consistent with the PCP-induced oxidative stress in catfish hepatocytes, since it was not expressed at a lower level of exposure.

\section{Vitellogenin Studies}

Estrogen plays a significant role in hepatic biosynthetic processes that are essential for oogenetic events in oviparous vertebrates. Vitellogenesis is an oogenetic activity by which estradiol, a natural estrogen, instructs the liver to synthesize and secrete Vtg. The activities of vitellogenesis are modulated by endogenous hormonal interactions between the hypothalamus, pituitary gland, and ovary follicle cell. Upon stimulation, the hypothalamus secretes gonadotrophinreleasing hormone that causes the pituitary gland to secrete gonadotrophic hormones in the blood. These hormones activate the follicle cell to produce estrogen, which instructs the liver to manufacture and secrete Vtg.

The synthesis of Vtg is an exclusive female-specific mechanism in oviparous animals. Although male fish possess the Vtg gene, it is normally inactive [22]. Several studies reported the induction of Vtg synthesis in male fish and other aquatic species is caused by the exposure to estrogenic compounds in the environment [50-52]. For example, organochlorine pesticides, including alachor, $\beta$-hexachlorocyclohexane (a lindane residue), DDT, and endosulfan II, bind to the estrogen receptor [53, 54] and cause, detrimental population consequences, depressed gonadal sex steroids, altered sex characteristics, and delayed sexual maturity [55-58]. 
An example of these deleterious effects was reported when a massive spill of dicofol, the DDT-like pesticide, was released into Florida lakes in the early 1980s. This accident resulted in a high incidence of altered sexual differentiation of the male reproductive tract and abnormal feminized steroid hormone profiles in juvenile alligators [55].

In the current study, the estrogenic activity of PCP was demonstrated by the up-regulation of the $125-\mathrm{kDa}$ Vtg protein in the hepatocytes of male channel catfish (Figure 4). Upon $48 \mathrm{hrs}$ of exposure, a time-dependent expression of vitellogenin to sublethal concentrations of PCP was observed. The up-regulation of this steroidinducible protein constitutes a clear indication of the endocrine-disrupting activity of PCP. This observation is consistent with a similar study that reported increased levels of Vtg in the male Japanese Medaka (Oryzias latipes) after exposure to 4-tert-octylphenol (OP), a chlorinated compound and known environmental estrogen [50].

\section{Conclusions}

Acute exposure to pentachlorophenol significantly reduces the viability of catfish hepatoctyes; the $\mathrm{LC}_{50}$ was computed to be about $2000 \mu \mathrm{g} \mathrm{PCP} / \mathrm{mL}$; indicating that PCP is acutely toxic to catfish hepatocytes. Exposure to lower levels of PCP caused a four-fold to eight-fold in cell proliferation, indicating the mitogenic effect of PCP in catfish hepatocytes. The over expression of the $c$-fos protein in this record is more indicative of the inflammatory response, in response to PCP-induced oxidative stress in fish hepatocytes. PCP has a potential to cause endocrine-disrupting activity in channel catfish as well as mimic hormonal estrogen. This was evidenced by the expression of the $125-\mathrm{kDa}$ vitellogenin protein.

Acknowledgments: This research was financially supported in part by a grant from the U. S. Department of Education (Grant No. P031B990006-01) through Title III Graduate Education Program, and in part by a grant from the National Institutes of Health (Grant No. 1GR12RR13459) through the RCMI-Center for Environmental Health at Jackson State University.

\section{References}

1. Dorsey, W. C.; Tchounwou, P. B.; Ishaque, A. B.; Shen, E.: Transcriptional activation of stress genes and cytotoxicity in human liver carcinoma $\left(\mathrm{HepG}_{2}\right)$ cells exposed to pentachlorophenol. Int. J. Mol. Sci., 2002, 3, 992-1007.

2. U.S. Environmental Protection Agency. Special report on environmental endocrine disruption: an effects assessment and analysis. EPA630R96012.
Prepared or the Risk Assessment forum. Washington, D.C., 1997.

3. Burow, M. E.; Yang, T.; Collins-Burow, B. M.; Krajewski, S; Reed, J. C.; McLachlan, J. A.; Beckman, B. S.: Effects of environmental estrogens on tumor necrosis factor $\alpha$-mediated apoptosis in MCF-7 cells. Carcinogenesis, 1999, 20, 11, $2057-$ 2061.

4. Yasuhara, A.; Katami, T.; Shibamoto, T.: Formation of PCDDs, PCDFs, and coplanar PCBs from incineration of various woods in the presence of chlorides. Environ. Sci Technol. 2003, 37, 15631567.

5. Huff, J. E.; Boyd, J. A.; Barrett, J. C.: Cellular and molecular mechanisms of hormonal carcinogenesis: environmental influences. New York: Wiley-Liss. 1996.

6. Cocco, P.; Kaxerouni, N.; Zahm, S. K.: Cancer mortality and environmental exposure to DDE in United States. Environ. Health Perspectives. 2000, 108, 1-4.

7. Alexander, R.: A developing toxic tort: lumber mills, log cabins, leukaemia, lymphomas and soft tissue sarcomas: the case against pentachlorophenol. The Consumer Law Page: Articles. 1999.

8. Colborn, T.; vom Saal F. S.; Soto, A. M.: Developmental effects of endocrine-disrupting chemicals in wildlife and humans. Environ. Health Perspectives. 1993, 101, 5, 256-257.

9. Guillette, L. J., Jr.; Gross, T. S.; Masson, G. R.; Matter, J. M.; Percival, H. F.; Woodward, A. R.: Developmental abnormalities of the gonad and abnormal sex hormone concentrations in juvenile alligators from contaminated and control lakes in Florida. Environmental Health Perspectives, 1994, 102, 608-688.

10. Kavlock, R., Ankley, G., Francis, E., Gray, E., McMaster, S., Reese, D., Sayles, G., Sergeant, A. and Vallero, D.: Research plan for endocrine disruptors: a report of the U.S. EPA. EPA600R98087 1998.

11. Beard, A. P.; Barthlewski, P. M.; Chandolia, R. K. Honaramooz, A.; Rawlings, N. C. :Reproductive and endocrine function in rams exposed to the organochlorine pesticides lindane and PCP from conception. J. Reproductive Fertility, 1999, 115, 303-14.

12. Beard, A. P.; Bartlewski, P. M; Rawlings, N. C.: Endocrine and reproductive function in ewes exposed to the organochlorine pesticides lindane or pentachlorophenol. J. Toxicol. Environ. Health. 1999, 56, 1: 23-46.

13. Colosio, C.; Maroni, M.; Barcellini, W.; Meroni, P.; Alcini, D.; Colombi, A.; Cavallo, D.; Foa, V.: Toxicological and immune findings in workers exposed to pentachlorophenol (PCP). Archives of Environmental Health, 1993, 48, 2, 81-88. 
14. Daniel, V.; Wolfgang, H.; Klausdieter, B.; and in patients with elevated pentachlorophenol (PCP) blood levels. Archives of Environmental Health. 1995, 50, 4, 287-292.

15. Miller, W. R.; Sharpe: Environmental oestrogens and human reproductive cancers. Endocrine-Related Cancer, 1998, 5, 69-96.

16. Peper, M.; Ertl, M.; Gerhard, I.: Long-term exposure to wood-preserving chemicals containing pentachlorophenol and lindane is related to neurobehavioral performance in women. American Journal of Industrial Medicine, 1999, 36.6, 632-41.

17. Rawlings, N. C.; Cook, S. J.; Waldbillig, D.: Effects of the pesticides carbofuran, chlorpyrifos, dimehoate, lindane, triallte, triluralin, 2,4-D, and pentachlorophenol on the metabolic endocrine and reproductive endocrine system in ewes. J. Toxicol. Environ. Health, 1998, 54, 21-36.

18. Danzo, B. J.: Environmental xenobiotics may disrupt normal endocrine function by interfering with the binding of physiological ligands to steroid receptor and binding proteins. Environmental Health Perspectives, 1997, 105, 294-301.

19. Illinois Environmental Protection Agency. Illinois EPA Endocrine Disruptors Strategy Document, 1997.

20. Fry, D. M.: Reproductive effects in birds exposed to pesticides and industrial chemicals. Environmental Health Perspectives, 1995. 103 (supplement 7): 165171.

21. Sumpter, J. P.; Jobling, S.: Vitellogenesis as a biomarker for estrogenic contamination of the aquatic environment. Environmental Health Perspectives, 1995, 103, 173-178.

22. Christiansen, T.; Korsgaard, B.; Jespersen, A.: Effects of nonylphenol and 17 $\beta$-oestradiol on vitellogenin synthesis, testicular structure and cytology in male eelpout Zoarces viviparus. J. Experimental Bio. 1998, 201, 179-192.

23. Hennies, M.; Wiesmann, M.; Allner, B.; Sauerwein, H.: Vitellogenin in carp (Cyprinus carpio) and (Perca fluviatilis: purification, characterization and development of an ELISA for the detection of estrogenic effects. Sci. Total Environ, 2003, 309, 93103.

24. Wallace, R. A.: Vitellogenesis and oocyte growth in nonmammlian vertebrates. In: Browder, L.W. (ed). Developmental biology: a comprehensive synthesis, vol 1: Oogenesis, New York, NY, 1985, p 127-177.

25. Palmer, B. D.; Palmer, S. K.: Vitellogenin induction by xenobiotic estrogens in the red-eared turtle and the African clawed frog. Environmental Health Perspectives, 1995, 103, 19-25.

26. Palmer, B. D.; Selcer, K. W.: Vitellogenin as a biomarker for xenobiotic estrogens: a review. In: Bengton, D. A.; Henshel, D. S. editors: Environmental toxicology and risk assessment: biomarkers and risk assessment. Volume 5. ASTM
Special Technical Publication nr 1306. Philadelphia (PA): American Society for Testing and Materials. 1996, p. 3-22.

27. Kinzell, J. H.; Ames, N. K.; Sleight, S. D.; Krehbiel, J. D.; Kuo, C.; Zabik; Shull, L. R.: Sub chronic administration of technical pentachlorophenol to lactating dairy cattle: performance, general health, and pathologic changes. J. Dairy Sci., 1981, 64, 4251.

28. Wood, S.; Rom, V. N.; White, G. L.; Logan, D. C.: Pentachlorophenol poisoning. J. Occup. Med., 1983, 25, 527-30.

29. Menzer, R. E.; Nelson, J. O.: Water and soil pollutants. In Casarett and Doull's Toxicology. C.D. Klaassen, Amdur, M. O.; Doull, J. (Eds.) $3^{\text {rd }}$ Ed. New York: Macmillan Publishing Co., 1986, pp. 825-853.

30. Bevenue, A.; Beckman, H.: Pentachlorophenol: a discussion of its properties and its occurrence as a residue in human and animal tissues. Residue Review 1967, 19:83-134.

31. Cirelli, D. P.: Patterns of pentachlorophenol usage in the United States of America: an overview. In K.r. Rao (ed.) pentachlorophenol: chemistry, pharmacology, and environmental toxicology. Plenum Press, New York, 1978, pp. 13-18.

32. U.S. National Toxicology Program (NTP 1991). Pentachlorophenol. NTP Chemical Repository. Report. Radian Corporation. 1991.

33. World Health Organization (WHO). Pentachlorophenol. Environmental Health Criteria 71. Geneva, 1987.

34. Office of Ground Water and Drinking Water (OGWDW). Technical Drinking Water and Health Contaminant Specific Fact Sheet. Technical fact sheet on pentachlorophenol. URL: http://www/epa.gov/OGWDW/dwh/tsoc/pentach, 1998.

35. Pignatello, J. J.; Martinson, J. G.; Steiert; Carlson, R. E.; Crawford, R. L.: Biodegradation and photolysis of pentachlorophenol in artificial freshwater streams. Applied Environmental Microbiology. 1983, 46, 1024-1031.

36. U.S. Department of Health and Human Services (DHHS). Toxicological Profile for Pentachlorophenol. Agency for Toxic Substance and Disease Registry. Draft. 1992.

37. Extension Toxicology Network (Extoxnet). Pentachlorophenol. Pesticide Information Profile. A Pesticide Information Project of Cooperative Extension Offices of Cornell University, Michigan State University, Oregon State University, and University of California at Davis. URL: http://pmep.cce.cornell.edu./profiles/extoxnet/metira m-propoxur/ pentachlorophenol-ext.html. 1998.

38. Agency for Toxic Substances and Disease Registry (ATSDR). Toxicological Profile for Pentachlorophenol (Draft). U.S. Public Health 
Service, U.S. Department of Health and Human Services, Atlanta, GA. 1992.

39. U.S. Environmental Protection Agency. Integrated Risk. Information System (IRIS) on Pentachlorophenol. Environmental Criteria and Assessment Office, Office of Health and Environmental Assessment, Office of Research and Development, Cincinnati, OH. 1993.

40. Wagner, S. L.: Clinical Toxicology of Agricultural Chemicals. Noyes Data Corporation. 1983.

41. Welsh, J. J.; Collins, T. F.; Black, T. N.; Graham, S. L.; O'Donnell Jr., M. W.: Teratogenic potential of purified pentachlorophenol and pentachloroanisole in sub chronically exposed Spague-Dawley rats. Food Chemical Toxicology. 1987, 25, 163-72.

42. Beard, A. P.; McRae, A. C.; Rawlings, N. C.: Reproductive efficiency in mink (Mustela vison) treated with the pesticides lindane, carofuran and pentachlorophenol. Journal of Reproductive Fertility. 1997, 111, 21-28.

43. Owens, K. D.; Baer, K. N.: Modifications of the topical Japanese medaka (Oryzias latipes) embryo larval assay for assessing developmental toxicity of pentachlorophenol and $\mathrm{p}, \mathrm{p}^{\prime}$ Dichlorodiphenyltrichloroethane. Ecotoxicology Environmental Safety. 2000, 47, 87-95.

44. Gerhard, I.; Frick, A.; Monga, B.; Runnebaum, B.: Pentachlorophenol exposure in women with gynaecological and endocrine dysfunction. Environmental Research. 1999, 80, 383-388.

45. Dorsey, W. C.; Tchounwou, P. B.; CYP1A1, HSP70, p53, and $c$-fos expression in human liver carcinoma cells $\left(\mathrm{HepG}_{2}\right)$ exposed to pentachlorophenol. The Instrumentation, Systems, and Automation Society. ISA 2003, 437, 389-396.

46. Pierce Jr., R. H.; Victor, D. M.: The fate of pentachlorophenol in an aquatic ecosystem. In Rao, K.R. (ed.), Pentachlorophenol: chemistry, pharmacology, and environmental toxicology. New York: Plenum Press. 1978, pp. 41-52.

47. Marino, M.; Acconcia, F.; Bresciana, R.; Weiz, A.; Trentalance, A.: Distinct nongenomic signal transduction pathways controlled by $17^{\beta}$-estradiol regulate DNA synthesis and Cyclin $\mathrm{D}_{1}$ gene transcription in $\mathrm{HepG}_{2}$ cells. Molecular Biology of the Cell. 2002, 13, 3720-3729.

48. Schreiber, M.; Kolbus, A.; Piu, F.; Szabowski, A.; Mohle-Steinlein, U.; Tian, J.; Karin, M.; Angel, P.; Wagner, E. F.: Control of cell cycle progression by c-jun is p53 dependent. Genes \& Development. 1999, 13, 617-619.
49. Wang, Z.; Templeton, D. M.: Induction of c-fos proto-oncogene in mesangial cells by cadmium. $J$. Bio. Chem. 1998, 273, 73-79.

50. Gronen, S.; Denslow, N.; Manning, S.; Barnes, S.; Barnes, D.; Brouwer: Serum vitellogenin levels and reproductive impairment of male Japanese Medaka (oryzias latipes) exposed to 4-tert-octylphenol. Environmental Health Perspectives, 1999, 107, 385 390.

51. Heppell, S. A.; Denslow, N. D.; Folmar, L. C.; Sullivan, C. V.: Universal assay of vitellogenin as a biomarker for environmental estrogens. Environmental Health Perspectives. 1995, 103 (Supplement 7), 9-15.

52. Monteverdi, G. H.; Di Giulio, R. T.: An enzymelinked immunosorbent assay for estrogenicity using primary hepatocyte cultures from the channel catfish (Ictalurus punctatus). Archives of Environmental Contamination and Toxicology. 1999, 37, 62-69.

53. Soto, A. M.; Chung, K. L.; Sonnenschein, C.: The pesticides endosulfan, toxaphene and dieldrin have estrogenic effects on human estrogen-sensitive cells. Environmental Health Perspective. 1994, 102, 380383.

54. Dewailly, E.; Ayotte, P.; Dodin, S.: Could the rising levels of estrogen receptor in breast cancer be due to estrogenic pollutants? Journal of the National Cancer Institute. 1997, 89, 888.

55. Cooper, R. L.; Kavlock, R. J.: Endocrine disruptors and reproductive development: a weight-of-evidence overview. Journal of Endocrinology. 1997, 152, 159-166.

56. Kunkel, J. G.: Serum and egg vitellogenin measurement in the Atlantic cod, Gadus morhua, and its relationship to ovarian development. Proposal response to CMER NOAA/NMFS Research Topic: Biochemical indices of maturity and egg auality in Atlantic cod. 1996.

57. Folmar, L. C.; Denslow, N. D.; Rao, V.; Chow, M.; Crain, A.; Enblom, J.; Marcino, J.; Guillette, L. J.: Vitellogenin induction and reduced serum testosterone concentration in Feral Male Carp (Cyprinus carpio) captured near a major metropolitan sewage treatment plant. Environmental Health Perspectives. 1996, 104, 1096.

58. Lye, C. M.; Frid, C. L. J.; Gill, M. E.; McCormick, D.: Abnormalities in the reproductive health of Flounder Platichthys flesus exposed to effluent from a sewage treatment works. Marine Pollution Bulletin. 1997, 34, 34-41. 